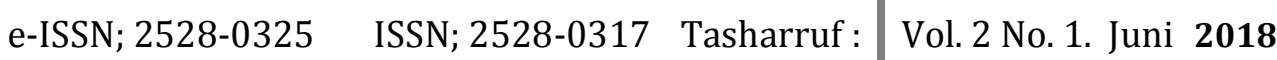
Journal Economic and Business Of Islam

Dampak Dana Alokasi Umum, Dana Alokasi Khusus, Dan Dana Bagi Hasil Terhadap Ketimpangan Produk Domestik Regional Bruto Di Provinsi Sulawesi Selatan Periode 2006-2014

The Implication Of General Allocation Fund, Special Allocation Fund, Profit Sharing Fund To Inequality The Gross Regional Domestic Product In South Sulawesi Province Period 2006-2014

\author{
Muhammad Azizi.,SE.,M.Si \\ muhazizii@gmail.com \\ Universitas Muslim Indonesia Makassar \\ Fakultas Ekonomi
}

Abstrak

Penelitian ini dilakukan bertujuan untuk: (1) mengetahui pengaruh komponen DAK (Dana Alokasi Khusus) terhadap berkurangnya ketimpangan Produk Domestik Regional Bruto (PDRB) Antar Kabupaten di Provinsi Sulawesi Selatan Periode 2005 - 2014; (2) mengetahui pengaruh komponen DAU (Dana Alokasi Umum) terhadap berkurangnya ketimpangan Produk Domestik Regional Bruto (PDRB) Antar Kabupaten di Provinsi Sulawesi Selatan Periode 2005 - 2014; (3) mengetahui pengaruh komponen DBH (Dana Bagi Hasil) terhadap berkurangnya ketimpangan Produk Domestik Regional Bruto (PDRB) Antar Kabupaten di Provinsi Sulawesi Selatan Periode 2005 - 2014.

Penelitian ini menggunakan data sekunder yang bersumber dari Badan Pusat Statistik Provinsi Sulawesi selatan, Data yang diperoleh adalah hasil akhir laporan Badan Pusat Statistik Provinsi Sulawesi selatan berupa PDRB, DAU, DAK, dan DBH Provinsi Sulawesi selatan tahun 2005-2014. Data disnalisis dengan menggunakan SPSS dan Indeks Williamson.

Hasil penelitian ini menunjukkan Hasil regresi linier berganda di atas menunjukkan bahwa variabel dana alokasi umum berpengaruh positif dan signifikan terhadap ketimpangan regional Sulawesi Selatan pada tahun 2005 s/d 2014, variabel dana alokasi khusus berpengaruh negatif dan signifikan terhadap ketimpangan regional Sulawesi Selatan pada tahun 2005 s/d 2014 dan variabel dana bagi hasil berpengaruh negatif dan signifikan terhadap ketimpangan regional Sulawesi Selatan pada tahun 2005 s/d 2014;

Hal ini menunjukkan bahwa menunjukan bahwa besarnya ketimpangan regional provinsi sulawesi selatan terjadi namun dikategorikan ketimpangan yang rendah karena nilai indeks williamson $<0,03$.

Kata Kunci: Dana Alokasi Umum, Dana Alokasi Khusus, Dana Bagi Hasil, dan Ketimpangan Regional

\title{
Abstract
}

Research aimed to: (1) the effect of components DAK (Special Allocation Fund) to the reduction of inequality Gross Regional Domestic Product (GRDP) Inter-district in South Sulawesi Province Period 2005-2014; (2) the effect of components DAU (General Allocation Fund) to the reduction of inequality Gross Regional Domestic Product (GRDP) Inter-district in South Sulawesi Province 
Period 2005-2014; (3) the effect of components $D B H(D B H)$ to the reduction of inequality Gross Regional Domestic Product (GRDP) Inter-district in South Sulawesi Province Period 2005-2014.

This study uses secondary data sourced from Statistics South Sulawesi province, data obtained is the result of the final report of the Central Statistics Agency in the form of the GDP of South Sulawesi province, DAU, DAK, DBH and southern Sulawesi province in 2005-2014. Data disnalisis by using SPSS and Williamson Index.

The results of this study indicate the results of multiple linear regression above shows that the variable of general allocation funds positive and significant impact on inequality regional South Sulawesi in 2005 s / d 2014, variable special allocation fund a significant negative effect on inequality regional South Sulawesi in $2005 \mathrm{~s} / \mathrm{d}$ in 2014 and a variable revenue-sharing significant negative effect on regional inequality South Sulawesi in 2005 s / d in 2014;This shows that shows that the magnitude of regional imbalances in South Sulawesi Province happened yet categorized inequality are low because williamson index values $<0.03$.

Keywords: General Allocation Fund, Special Allocation Fund, DBH and Regional Inequality

Pendahuluan

Sebagai suatu negara dengan ribuan pulau, perbedaan karakteristik wilayah adalah konsekuensi logis yang tidak dapat dihindari Indonesia. Karena karakteristik wilayah mempunyai pengaruh kuat pada terciptanya pola pembangunan ekonomi, sehingga suatu keniscayaan bila pola pembangunan ekonomi di Indonesia tidak seragam. Ketidakseragaman ini berpengaruh pada kemampuan untuk tumbuh, yang pada gilirannya mengakibatkan beberapa wilayah mampu tumbuh dengan cepat sementara wilayah lainnya tumbuh lambat. Kemampuan tumbuh yang berbeda ini pada akhirnya menyebabkan terjadinya ketimpangan antar daerah.

Oxfam Indonesia dan International NGO Forum on Indonesia Development (INFID) dalam laporannya yang berjudul "Menuju Indonesia yang Lebih Setara", mencatat peringkat ketimpangan ekonomi Indonesia berada di posisi enam terburuk di dunia. Pertumbuhan ekonomi Indonesia dinilai cukup stabil dan proporsi masyarakat yang hidup dalam kemiskinan ekstrim telah berkurang menjadi sekitar 8 persen. Namun, Oxfam dan INFID menilai, capaian pertumbuhan ekonomi tersebut belum diimbangi dengan pembagian pendapatan yang lebih merata. Selama dua dekade terakhir, ketimpangan antara kelompok terkaya dan kelompok yang lain di Indonesia mengalami peningkatan yang lebih cepat dibanding negara-negara di Asia Tenggara. Tak hanya itu, laporan tersebut juga mencatat kekayaan empat orang terkaya di Indonesia sama dengan gabungan kekayaan 100 juta orang termiskin, (Kompas. Kamis, 23 Februari 2017). Pada tahun 2004, ketika presiden SBY baru mulai berkuasa angka rasio gini tercatat sekitar 0,32 dan 20 persen masyarakat berpendapatan tertinggi menguasai 40 persen pendapatan nasional. Pada tahun 2012, rasio gini memburuk ke 0,41 dan 20 persen masyarakat perpenghasilan tertinggi menguasai 48 persen pendapatan nasional. Seperti yang di tunjukkan, 5,7 tren perkembangan tingkat 
kesenjangan pendapatan cenderung berkorelasi positif dengan tren laju pertumbuhan ekonomi, bukannya negative, seperti yang di harapkan. Ada kesepakatan umum yang tidak tertulis bahwa nilai koefisien gini di bawah 0,4 artinya tingkat ketimpangan rendah; antara 0,4 hingga 0,5 ketimpangan sedang; dan di atas 0,5 ketimpangan besar (Tambunan,2015:130).

Pertumbuhan ekonomi yang tinggi hanya berimbas pada tingkat nasional tidak serta pada tingkatan daerah. Sehingga menyebabkan terjadinya ketimpangan antar kawasan di Indonesia. Sebagai upaya dalam mengatasi ketimpangan daerah, pada tahun 2001 pemerintah Indonesia memberlakukan sebuah kebijakan yaitu kebijakan otonomi daerah dan kebijakan desentralisasi fiskal. Dengan alasan, bahwa kebijakan pembangunan yang ditetapkan pemerintah pusat tidak semunya bisa diterapkan di seluruh daerah, daerah yang memiliki daya dukung dan sesuai dengan kriteria kebijakan nasional akan dengan mudah menyerap peluang pembangunan, sedangkan daerah yang tidak sesuai kriteria kebijakan nasional akan mengalami perlambatan dalam pembangunan.

Pembangunan daerah dapat dilakukan melalui dua pendekatan, yakni pendekatan sentralisasi dan pendekatan desentralisasi. Pendekatan sentralisasi mengandung arti bahwa pelaksanaan pembangunan sepenuhnya merupakan wewenang pusat dan dilaksanakan oleh para birokrat di pusat. Sedangkan pendekatan desentralisasi mengandung arti bahwa pembangunan daerah melalui desentralisasi atau otonomi daerah memberikan peluang dan kesempatan bagi terwujudnya pemerintahan yang bersih dan baik (good governance) di daerah. Artinya pelaksanaan tugas pemerintah daerah harus didasarkan atas prinsip efektif, efisien, partisipatif, terbuka (transparency), dan akuntabilitas (accountability). Kebijakan dan tugas umum pemerintahan serta implementasi pembangunan di daerah di masa lampau merupakan wewenang dan tanggung jawab penuh dari pemerintah pusat, Jakarta. Kewenangan pemerintah pusat yang sangat besar tersebut ternyata tidak hanya berdampak positif bagi pembangunan, tetapi disadari juga menimbulkan efek negatif antara lain pertumbuhan ekonomi daerah atau produk domestik regional bruto (gross domestic regional product) yang relatif sangat lamban, serta panjangnya birokrasi pelayanan publik karena harus menunggu petunjuk dari para pejabat pusat. Hal ini menimbulkan keterlambatan pembangunan di daerah daerah terutama bagi daerah - daerah yang jauh dari pemerintah pusat, Jakarta.

Segala kebijakan yang diatur dan diputuskan oleh pemerintah pusat, termasuk keuangan daerah menyebabkan banyak kepentingan dan kebutuhan daerah yang tidak terakomodir. Pemerintah pusat mengambil kebijakan dari sudut pandang mereka bukan dari sudut pandang daerah. Sementara yang mengetahui kebutuhan daerah adalah daerah itu sendiri bukan pemerintah pusat. Beranjak dari permasalahan yang timbul di masa pemerintahan sentralistik maka pemerintah merumuskan undang - undang mengenai otonomi daerah. Indonesia memasuki era otonomi daerah sejak tanggal 1 Januari 2000. Pelaksanaan otonomi daerah mengacu pada UU nomor 22 tahun 1999 mengenai pembagian kewenangan dan fungsi (power sharing) antara pemerintah pusat dan daerah dan UU nomor 25 tahun 1999 perimbangan keuangan pusat dan daerah yaitu pengaturan pembagian sumber-sumber daya keuangan (financial sharing) antara pusat-daerah sebagai konsekuensi dari adanya pembagian kewenangan tersebut. 
Otonomi daerah dan desentralisasi fiskal bukan konsep baru di Indonesia, sudah diatur dalam UU RI No. 5 tahun 1975 tentang pokok-pokok pemerintahan di daerah. Dalam prakteknya kebijakan otonomi daerah dan desentralisasi fiskal selama pemerintahan orde baru belum dapat mengurangi ketimpangan vertikal dan horisontal, yang ditunjukkan dengan tingginya derajat sentralisasi fiskal dan besarnya ketimpangan antardaerah dan wilayah (Uppal dan Suparmoko, 1986; Sjahfrizal, 1997). Praktek internasional desentralisasi fiskal baru dijalankan pada 1 Januari 2001 berdasarkan UU RI No. 25 tahun 1999 yang disempurnakan dengan UU RI No. 33 tahun 2000 tentang perimbangan keuangan antara pemerintah pusat dan pemerintah daerah. Pengalihan pembiayaan atau desentralisasi fiskal secara singkat dapat diartikan sebagai suatu proses distribusi anggaran dari tingkat pemerintahan yang lebih tinggi kepada pemerintahan yang lebih rendah, untuk mendukung fungsi atau tugas pemerintahan dan pelayanan publik sesuai dengan banyaknya kewenangan bidang pemerintahan yang dilimpahkan (Saragih, 2003: 83). Prinsip dasar pelaksanaan desentralisasi fiskal di Indonesia ialah "Money Follows Functions", yaitu fungsi pokok pelayanan publik didaerahkan, dengan dukungan pembiayaan pusat melalui penyerahan sumbersumber penerimaan kepada daerah. Prinsip tersebut berarti setiap penyerahan atau pelimpahan wewenang pemerintahan membawa konsekuensi pada anggaran yang diperlukan untuk melaksanakan kewenangan tersebut (Ibid : 83).

Bahl dan Linn (1992:391) berpendapat bahwa pendelegasian sebagian urusan keuangan publik dari pemerintah pusat kepada pemerintah daerah merupakan konsekuensi dari pencapaian taraf hidup masyarakat yang lebih baik. Pernyataan ini didukung oleh dua argument sebagai berikut. Pertama, median vote theory yang memaparkan tentang respon dunia usaha atas selera dan preferensi masyarakat daerah. Pelayanan publik disesuaikan dengan kehendak dan permintaan masyarakat setempat. Kedua, Fiskal mobility theory yang menggambarkan tingkat mobilitas penduduk antardaerah yang dipicu oleh tingkat kesejahteraan masyarakat yang lebih tinggi. Perbaikan kualitas hidup orang akan mendorong mereka untuk memilih daerah yang menyediakan pelayanan publik yang lebih baik (Bahl dan Linn 1992). Dengan demikian, pembangungan ekonomi suatu daerah akan berimbas pada penciptaan sektor public di daerah (Oates 1993). Bertolak belakang dari pendapat di atas sebelumnya, Oates (1972) menegaskan bahwa tingkat kemajuan ekonomi merupakan outcome dari kesesuaian preferensi masyarakat dengan Pemerintah Daerah yang tercipta karena makin pentingnya peran Pemerintah Daerah dalam otonomi daerah. Secara teori, pendelegasian fiskal kepada pemerintah yang berada di level bawah diperkirakan memberikan peningkatan ekonomi mengingat pemerintah daerah memiliki kedekatan dengan masyarakatnya dan mempunyai keunggulan informasi dibandingkan dengan pemerintah pusat, sehingga dapat memberikan pelayanan publik yang benar-benar dibutuhkan di daerahnya. Respon yang diberikan oleh pemerintah daerah terhadap tuntutan masyarakat jauh lebih cepat karena mereka berhadapan langsung dengan penduduk daerah/kota yang bersangkutan. Argumentasi lain yang mendasari adalah munculnya "kompetisiee atau persaingan antardaerah akan meningkatkan kesamaan pandangan antara apa yang diharapkan oleh masyarakat dengan suatu program yang dijalankan oleh pemerintahnya (Davoodi dan Zou 1998:244). Sejalan dengan hal tersebut, Oates (1993) berpendapat bahwa desentralisasi fiskal berpotensi memberikan kontribusi dalam bentuk peningkatan efisiensi 
pemerintahan dan laju pertumbuhan ekonomi. Disamping itu, berdasarkan hasil analisis atas 58 negara ditemukan bahwa rendahnya tingkat desentralisasi fiskal akan mereduksi tingkat pendapatan per kapita masyarakat (Oates 1993:237).

Dalam desentralisasi fiskal, dana perimbangan merupakan komponen utama. Dana perimbangan merupakan inti dari desentralisasi dimana perimbangan keuangan antara pemerintah pusat dan pemerintahan daerah berupa sistem keuangan yang diatur berdasarkan pembagian kewenangan, tugas, dan tanggung jawab yang jelas antarsusunan pemerintahan. Ada perbedaan sudut pandang di dalam menyikapi masalah dana perimbangan ini. Di satu sisi, adanya dana perimbangan dalam otonomi daerah merupakan bentuk tanggung jawab dari pemerintah pusat atas berjalannya proses otonomi daerah. Hal ini juga sebagai wujud walaupun sistem yang diterapkan adalah sistem otonomi daerah, akan tetapi tetap dalam kerangka Negara Kesatuan Republik Indonesia. Namun di sisi yang lain, adanya dana perimbangan yang terlalu besar akan menimbulkan persepsi bahwa daerah tersebut tidak mandiri secara fiskal dan akan sampai pada kesimpulan akhir bahwa otonomi daerah tidak efektif untuk dilaksanakan. Pengalaman selama ini menunjukkan bahwa hampir di semua daerah prosentase Pendapatan Asli Daerah, relatif lebih kecil, sekitar 25\% dari total penerimaan daerah. Pada umumnya APBD (Anggaran Pendapatan dan Belanja Daerah) suatu daerah didominasi oleh sumbangan pemerintah pusat dan sumbangan-sumbangan lain, yang diatur dengan peraturan perundang-undangan, yaitu sekitar $75 \%$ dari total penerimaan daerah (Yani, 2002: 3). Hal ini menyebabkan daerah masih tergantung kepada pemerintah pusat, sehingga kemampuan daerah untuk mengembangkan potensi yang mereka miliki menjadi sangat terbatas. Rendahnya PAD suatu daerah bukanlah disebabkan oleh karena secara struktural daerah memang miskin atau tidak memiliki sumber-sumber keuangan yang potensial, tetapi lebih banyak disebabkan oleh kebijakan pemerintah pusat. Idealnya seluruh pengeluaran daerah dapat ditutupi oleh Pendapatan Asli Daerah sehingga seluruh daerah dapat benar - benar otonomi akan tetapi peranan PAD terhadap pengeluaran daerah semakin menurun. Dengan menurunnya peranan PAD ini mengindikasikan bahwa dana perimbangan yang diterima pemerintah daerah dari pemerintah pusat semakin bertambah untuk menutupi kekurangan dana yang ada di daerah.

Sulawesi Selatan sebagai salah satu provinsi di Indonesia juga mendapatkan dana perimbangan setiap tahunnya. Dana perimbangan ini kemudian dialokasikan ke kabupaten/kota se-Sulawesi Selatan yang jumlahnya berbeda satu sama lain. Perbedaan alokasi dana perimbangan ini menyebabkan terjadinya ketimpangan pertumbuhan ekonomi antara masing- masing kabupaten/kota. Dampak positif diberlakukannya desentralisasi fiskal pada pertumbuhan ekonomi, dapat dilihat dari perkembangan ekonomi di Sulawesi selatan.

Tabel 1

Produk Domestik Regional Bruto Atas Dasar Harga Konstan Provinsi Sulawesi Selatan Tahun 2010-2014

\begin{tabular}{|c|c|c|}
\hline No & Tahun & PDRB (Milyar Rupiah) \\
\hline 1 & 2005 & $36.421,79$ \\
\hline 2 & 2006 & $38.867,68$ \\
\hline
\end{tabular}




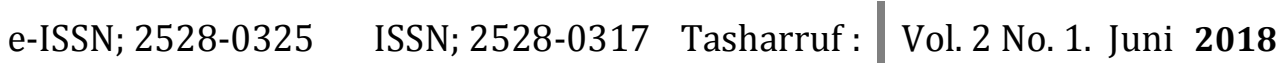
Journal Economic and Business Of Islam

\begin{tabular}{|c|c|c|}
\hline 3 & 2007 & $41.332,43$ \\
\hline 4 & 2008 & $44.549,82$ \\
\hline 5 & 2009 & $47.314,20$ \\
\hline 6 & 2010 & $51.199,90$ \\
\hline 7 & 2011 & $55.116,92$ \\
\hline 8 & 2012 & $56.466,90$ \\
\hline 9 & 2013 & $58.123,02$ \\
\hline 10 & 2014 & $59.106,82$ \\
\hline \multicolumn{2}{|c|}{ Total } & $\mathbf{4 8 8 . 4 9 9 , 4 8}$ \\
\hline
\end{tabular}

Sumber : BPS Sulawesi selatan, data diolah

Berdasarkan tabel 1 dapat diketahui bahwa jumlah PDRB Provinsi Sulawesi Selatan mengalami peningkatan setiap tahunnya, kenaikan PDRB terbesar terjadi pada tahun 2011, dimana pada tahun 2010 jumalah PDRB Provinsi Sulawesi Selatan sebesar Rp. 51.199,90 Milyar dan 2011 mencapai Rp. 55.116,92 Milyar. Adapun total PDRB dari tahun 2005-2014 Rp. 488.499,48 Milyar. Hal ini menunjukkan bahwa tingkat perkonomian Sulawesi selatan secara keseluruhan mengalami kenaikan.

Tabel 2

Pertumbuhan Ekonomi Provinsi Sulawesi Selatan Tahun 2010-2014

\begin{tabular}{|c|c|c|}
\hline No & Tahun & Pertumbuhan Ekonomi (\%) \\
\hline 1 & 2010 & 8,19 \\
\hline 2 & 2011 & 8,13 \\
\hline 3 & 2012 & 8,17 \\
\hline 4 & 2013 & 7,63 \\
\hline 5 & 2014 & 7,57 \\
\hline \multicolumn{2}{|c|}{ Rata-rata } & $\mathbf{7 , 9 3}$ \\
\hline
\end{tabular}

Sumber : BPS Sulawesi selatan, data diolah

Berdasarkan tabel 2 diatas dapat diketahui bahwa pertumbuhan ekonomi provinsi Sulawesi selatan 2010-2014 mengalami fluktuasi. dari tahun 2010-2014 rata-rata pertumbuhan ekonomi Sulawesi selatan 7,93. Hal ini menunjukkan bahwa tingkat pertumbuhan ekonomi Sulawesi selatan secara keseluruhan cenderung positif. Selanjutnya dikatakan bahwa pengaruh positif atau negatif dari pertumbuhan penduduk tergantung pada kemampuan sistem perekonomian daerah tersebut dalam menyerap dan secara produktif memanfaatkan pertambahan tenaga kerja tersebut. Kemampuan tersebut dipengaruhi oleh tingkat dan jenis akumulasi modal dan tersedianya input dan faktor penunjang seperti kecakapan manajerial dan administrasi. Dalam model sederhana tentang pertumbuhan ekonomi, pada 
umumnya pengertian tenaga kerja diartikan sebagai angkatan kerja yang bersifat homogen.

Berdasarkan uraian latarbelakang, Sulawesi selatan memiliki kondisi perekonomian yang cukup baik, namun disertai dengan ketimpangan pembangunan ekonomi yang semakin meningkat. Oleh karena itu, peneliti mengangkat judul "Dampak Dana Alokasi Umum, Dana Alokasi Khusus, Dan Dana Bagi Hasil Terhadap Ketimpangan Produk Domestik Regional Bruto Di Provinsi Sulawesi Selatan Periode 2006 - 2014”.

Rumusan Masalah

Berdasarkan pemaparan pada latar belakang maka permasalahan dalam rencana penelitian ini dapat dirumuskan sebagai berikut:

1. Apakah DAK (Dana Alokasi Khusus) berpengaruh terhadap berkurangnya ketimpangan Produk Domestik Regional Bruto (PDRB) Antar Kabupaten di Provinsi Sulawesi Selatan Periode 2006 - 2014?

2. Apakah DAU (Dana Alokasi Umum) berpengaruh terhadap berkurangnya ketimpangan Produk Domestik Regional Bruto (PDRB) Antar Kabupaten di Provinsi Sulawesi Selatan Periode 2006 - 2014?

3. Apakah DBH (Dana Bagi Hasil) berpengaruh terhadap berkurangnya ketimpangan Produk Domestik Regional Bruto (PDRB) Antar Kabupaten di Provinsi Sulawesi Selatan Periode 2006 - 2014?

Tinjauan Pustaka

Desentralisasi Fiskal

Sejak tahun 2001, dengan diberlakukannya UU No.22 Tahun 1999 tentang Pemerintahan Daerah, dan UU No.25 Tahun 1999 tentang Perimbangan Keuangan antara Pemerintah Pusat dan Daerah ( sekarang kedua UU di atas sudah diganti dengan UU No. 32 tahun 2004 dan UU No. 33 tahun 2004), maka pemerintah daerah di Indonesia memiliki kewenangan yang seluas-luasnya dalam pelaksanaan pemerintahan dan pengaturan keuangan daerahnya masing-masing.

Dalam UU No.32 tahun 2004 dijelaskan bahwa pelaksanaan urusan pemerintahan oleh daerah dapat diselenggarakan secara langsung oleh pemerintahan daerah itu sendiri dan dapat pula penugasan oleh pemerintah provinsi ke pemerintah kabupaten/kota dan desa atau penugasan dari pemerintah kabupaten/kota ke desa. Dalam UU No.33 tahun 2004 dijelaskan bahwa Perimbangan Keuangan antara Pemerintah dan Pemerintahan Daerah merupakan bagian pengaturan yang tidak terpisahkan dari sistem Keuangan Negara dan dimaksudkan untuk mengatur sistem pendanaan atas kewenangan pemerintahan yang diserahkan, dilimpahkan, dan ditugasbantukan kepada Daerah. Selain UU No.32 tahun 2004 dan UU No.33 tahun 2004, konsep desentralisasi juga diperkuat oleh Peraturan Pemerintah Republik Indonesia No. 55 tahun 2005 tentang dana perimbangan.

Dalam mendefinisikan desentralisasi, beberapa ahli menggunakan pandangan dan perspektifnya masing-masing. Parson (1961) dalam Hidayat (2004) mendefinisikan desentralisasi sebagai berikut: "sharing of the govermental power by a central ruling group with other groups, each having autority within a specific area of the state". Pada bagian lain, Smith (1985) dalam Hidayat (2004) merumuskan definisi desentralisasi berdasarkan perspektif politik, yakni: "the 
transfer of power from top level to lower level, in a territorial hierarchy, witch could be one of goverment within a state, or offices within a large organisation".

\section{Dana Perimbangan}

Dana perimbangan daerah adalah dana yang bersumber dari pendapatan APBN yang dialokasikan kepada daerah untuk mendanai kebutuhan daerah dalam rangka pelaksanaan desentralisasi. Dana Perimbangan terdiri atas Dana Alokasi Umum (DAU), Dana Alokasi Khusus (DAK), Dana Bagi Hasil (DBH). Dana Alokasi Umum (DAU) adalah dana yang bersumber dari pendapatan APBN yang dialokasikan dengan tujuan pemerataan kemampuan keuangan antar daerah untuk mendanai kebutuhan daerah dalam rangka pelaksanaan desentralisasi. DAU dialokasikan untuk provinsi dan kabupaten/kota.

DAU bertujuan untuk pemerataan kemampuan keuangan antar daerah yang dimaksudkan untuk mengurangi ketimpangan kemampuan keuangan antardaerah melalui penerapan formula yang mempertimbangkan kebutuhan dan potensi daerah. DAU suatu daerah ditentukan atas besar kecilnya celah Fiskal (Fiskal gap) suatu daerah, yang merupakan selisih antara kebutuhan daerah (Fiskal need) dan potensi daerah (Fiskal capacity). Perubahan dalam Undang - Undang Nomor 33 Tahun 2004 menegaskan kembali mengenai formula celah Fiskal dan penambahan variable DAU. Alokasi DAU bagi daerah yang potensi fiskalnya besar, tetapi kebutuhan Fiskal kecil akan memperoleh alokasi DAU relative kecil. Sebaliknya, daerah yang potensi fiskalnya kecil, namun kebutuhan Fiskal besar, akan memperoleh alokasi DAU relative besar. Secara implicit, prinsip tersebut menegaskan fungsi DAU sebagai factor pemerataan kapasitas Fiskal.

\section{Pertumbuhan Ekonomi Daerah}

Pertumbuhan ekonomi merupakan suatu perubahan tingkat kegiatan ekonomi yang berlangsung dari tahun ke tahun (Sadono,1985:19), sehingga untuk mengetahui tingkat pertumbuhan ekonomi harus dibandingkan pendapatan nasional dari berbagai tahun yang dihitung berdasarkan harga konstan dan harga berlaku. Perubahan dalam nilai pendapatan nasional hanya disebabkan oleh suatu perubahan dalam suatu tingkat kegiatan ekonomi.

Pertumbuhan ekonomi adalah proses kenaikan output per kapita dalam jangka panjang (Boediono,1999:1). Pertumbuhan ekonomi berkaitan dengan kenaikan output per kapita. Di sini ada dua sisi penting yaitu output total dan jumlah penduduk. Output per kapita adalah output total dibagi jumlah penduduk. Aspek ketiga dari definisi pertumbuhan ekonomi adalah perspektif waktu jangka panjang. Kenaikan output per kapita selama satu atau dua tahun, yang kemudian diikuti dengan penurunan output per kapita bukan pertumbuhan ekonomi. Suatu perekonomian dikatakan tumbuh apabila dalam jangka waktu 5 tahun mengalami kenaikan output per kapita. Menurut Kuznets, pertumbuhan ekonomi adalah kenaikan kapasitas dalam jangka panjang dari negara yang bersangkutan untuk menyediakan berbagai barang ekonomi kepada penduduknya. Kenaikan kapasitas itu sendiri ditentukan atau dimungkinkan oleh adanya kemajuan atau penyesuaianpenyesuaian teknologi, institusional (kelembagaan), dan idiologis terhadap berbagai tuntutan keadaan yang ada (Smith dan Todaro, 2004).

Ketimpangan Produk Domestik Regional Bruto 
Berhasilnya suatu pembangunan oleh suatu daerah dapat dilihat dari perkembangan indikator-indikator perekonomian yang ada, apakah mengalami peningkatan atau penurunan. Produk Domestik Regional Bruto (PDRB) termasuk dalam salah satu indikator pembangunan suatu daerah. Secara tradisional, pembangunan memiliki arti peningkatan PDRB secara terus menerus. Pembangunan suatu daerah yang baik juga harus diikuti pembangunan ekonomi yang baik juga disetiap daerah. Hal ini bisa dilihat dari periode ke periode lainnya bahwa kemampuan suatu daerah untuk menghasilkan barang dan jasa akan meningkat. Kemampuan yang meningkat ini disebabkan karena faktor-faktor produksi mengalami pertambahan dalam jumlah dan kualitasnya. Salah satu faktor peningkatan atau penurunan pembangunan ekonomi daerah ialah ketimpangan Produk Domestik Regional Bruto yang tidak merata.

Ketimpangan merupakan suatu fenomena yang terjadi hampir di lapisan negara di dunia, baik itu negara miskin, negara sedang berkembang, maupun negara maju, hanya yang membedakan dari semuanya itu yaitu besaran tingkat ketimpangan tersebut, karenanya ketimpangan itu tidak mungkin dihilangkan namun hanya dapat ditekan hingga batas yang dapat ditoleransi.

Myrdal (1957) dalam Jhingan (2004) menerangkan ketimpangan antar daerah dengan membangun teori keterbelakangan dan pembangunan ekonominya di sekitar ide ketimpangan pada taraf nasional dan internasional. Untuk menjelaskan hal itu, Myrdal menggunakan ide spread effect dan backwash effect sebagai bentuk pengaruh penjalaran dari pusat pertumbuhan ke daerah sekitar. Spread effect didefinisikan sebagai suatu pengaruh yang menguntungkan (favorable effect), yang mencakup aliran kegiatan-kegiatan investasi dari pusat pertumbuhan ke wilayah sekitar.

\section{Indeks Williamson}

Indeks Williamson ini diperkenalkan oleh Jeffry G Williamson (1965), penghitungan nilai ini didasarkan pada coeffisient of variation (CV) dan Williamson memodifikasi perhitungan ini dengan menimbangnya dengan proporsi penduduk wilayah.

Berbeda halnya dengan gini coeffisient yang menghitung nilai distribusi pendapatan seluruh rumah tangga dalam suatu daerah atau negara, indeks Williamson ini dapat melihat besarnya ketimpangan distribusi pendapatan antar daerah dalam sebuah wilayah. Semakin besar angka indeks Williamson ini maka semakin besar pula tingkat ketimpangan yang terjadi. Indeks ini dapat dihitung dengan rumus:

$$
C V_{w}=\frac{\sqrt{\sum_{i}\left(Y_{i}-\bar{Y}\right)^{2} \cdot \frac{F_{i}}{n}}}{\bar{Y}}
$$

dimana:

$\mathrm{CVw}=$ Indeks ketimpangan pendapatan wilayah

$\mathrm{F}_{\mathrm{i}} \quad=$ Jumlah penduduk di kab/kota $\mathrm{i}$

$\mathrm{n} \quad=$ Jumlah penduduk provinsi 
$\mathrm{Y}_{\mathrm{i}} \quad=$ Pendapatan perkapita di kab/kota $\mathrm{i}$

$Y \quad=$ Rata-rata pendapatan perkapita untuk seluruh propinsi

Batasan tingkat ketimpangan antar wilayah dengan menggunakan ukuran ini, yaitu:

Nilai indeks $>1$, terjadi ketimpangan yang maksimum

Nilai indeks $0,7-1$, terjadi ketimpangan yang tinggi

Nilai indeks $0,4-0,6$, terjadi ketimpangan yang sedang

Nilai indeks $<0,3$, terjadi ketimpangan yang rendah

Hubungan Ketimpangan Daerah terhadap dana perimbangan

Kusnetz (1957) dalam Tambunan (2003) mengemukakan suatu pola hubungan antara pertumbuhan dan pemerataan. Pola ini dikenal dengan "Hipotesis U Terbalik". Hipotesis ini dihasilkan melalui suatu kajian empiris terhadap pola pertumbuhan sejumlah negara didunia, pada tahap awal pertumbuhan ekonomi terdapat trade-off antara pertumbuhan dan pemerataan. Pola ini disebabkan karena pertumbuhan pada tahap awal pembangunan cenderung dipusatkan pada sektor modern perekonomian yang pada saat itu kecil dalam penyerapan tenaga kerja. Ketimpangan membesar karena kesenjangan antar sektor modern dan tradisional meningkat. Peningkatan tersebut terjadi karena perkembangan disektor modern lebih cepat dibandingkan dengan sektor tradisional. Akan tetapi dalam jangka panjang, pada saat kondisi ekonomi mencapai tingkat kedewasaan (maturity) dan dengan asumsi mekanisme pasar bebas serta mobilitas semua faktor-faktor produksi antar negara tanpa sedikitpun rintangan atau distorsi, maka perbedaan dalam laju pertumbuhan output antar negara akan cenderung mengecil bersamaan dengan tingkat pendapatan perkapita dan laju pertumbuhan rata-ratanya yang semakin tinggi di setiap negara, yang akhirnya menghilangkan kesenjangan.

Ketimpangan Pembangunan Antar Wilayah

Kegiatan Ekonomi suatu daerah, ketimpangan pembangrnan antar wilayah merupakan faktor yang biasa terjadi. Ketimpanga ini biasanya disebabkan adanya perbedaan tingkat sumber daya alam dan faktor lain yang terdapat pada daerah masing-masing, Dengan adanya perbedaan tersebut membuat kemampuan daerah dalam mendorong proses pembangunan juga berbeda.

Menurut Sjafrizal, (2008:104) maka tidaklah mengherankan bila setiap daerah biasanya terdapat wilayah maju (Developed Region) dan wilayah terbelakang (Underdeloped Region). Terjadinya ketimpangan antar wilayah akan membawa pengaruh terhadap tingkat kesejahteraan masyarakat antar wilayah. Untuk melihat ketimpangan pembangunan antar wilayah dalam suatu daerah tidaklah mudah.banyak argument yang menjelaskan bahwa ketimpangan ada karena banyaknya kemiskinan pada suatu wilayah dan juga banyak yang berpendapat bahwa ketimpangan terjadi karena adanya kemiskinan ditengah kemapanan masyarakat. Namun dalam ketimpangan pembangunan antar wilayah ini yang menjadi focus bukan antar kelompok kaya dan miskin melainkan adanya daerah yang tertinggal dan daerah yang maju. 


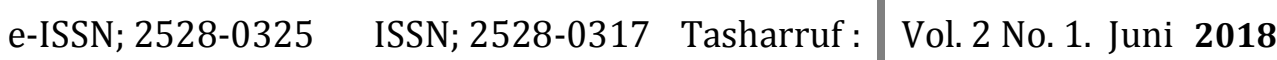
Journal Economic and Business Of Islam

Hubungan Pola Perekonomian Daerah dengan Ketimpangan Pembangunan Ekonomi Daerah

Pembangunan ekonomi suatu daerah tidak serta merta dipandang sebagai kenaikan pertumbuhan ekonomi, melainkan juga mempertimbangkan adanya pertumbuhan penduduk serta perombakan dan modernisasi struktur ekonominya (transformasi struktural) (Arsyad, 1999). Setelah adanya otonomi, keberhasilan pembangunan ekonomi daerah dapat ditentukan oleh adanya keuntungan lokasi pada daerah tersebut. Seperti yang dapat dijelaskan dalam teori basis ekspor, bahwa suatu daerah tidak harus menjadi daerah industri untuk dapat tumbuh dengan cepat, sebab faktor penentu pertumbuhan adalah keuntungan komparatif yang dimiliki oleh daerah bersangkutan. Apabila pemanfaatan keuntungan komparatif yang dimiliki menjadi kekuatan basis ekspor maka pertumbuhan ekonomi dapat dimaksimalkan.

Sedangkan berdasarkan teori Neo Klasik, pertumbuhan ekonomi suatu daerah ditentukan oleh kemampuan wilayah tersebut untuk meningkatkan kegiatan produksinya. Pertumbuhan ekonomi wilayah selain ditentukan oleh potensi daerah, tetapi juga ditentukan oleh mobilitas tenaga kerja dan mobilitas modal antar daerah. Namun modal dan tenaga kerja ahli cenderung terkosentrasi di daerah yang lebih maju sehingga ketimpangan pembangunan wilayah cenderung melebar.

Penelitian Terdahulu

Masli (2006) dalam penelitiannya tentang Analisis Faktor - factor yang Mempengaruhi Pertumbuhan Ekonomi dan Ketimpangan Regional Antar Kabupaten/Kota di Propinsi Jawa Barat tahun 1993 - 2006. Menyimpulkan bahwa tingkat ketimpangan antar kabupaten/kota di Provinsi Jawa Barat tahun 1993 - 2006 berdasarkan Indeks Ketimpangan Williamson dan Indeks Ketimpangan Entropi Theil cenderung meningkat. Penyebabnya adalah perubahan laju pertumbuhan ekonomi yang negatif, baik secara langsung maupun tidak langsung akan berpengaruh terhadap masalah ketimpangan regional.

Fatimah (2007) dalam penelitiannya tentang Dampak Kebijakan Desentralisasi Fiskal Terhadap Ketimpangan Pendapatan Antar Propinsi di Indonesia Tahun 1993 - 2004. Dengan menggunakan Indeks Ketimpangan Williamson menyimpulkan bahwa ketimpangan transfer Fiskal berpengaruh negatif dan signifikan secara statistik terhadap ketimpangan pendapatan. Dengan meningkatnya ketimpangan transfer fiskal ini maka akan menurunkan tingkat ketimpangan pendapatan. Lebih jauh, karena peningkatan ketimpangan transfer fiskal ini disebabkan oleh meningkatnya dana transfer yang diperoleh pemerintah daerah. Maka hal ini pun akan berarti bahwa peningkatan dana transfer akan berdampak terhadap penurunan tingkat ketimpangan pendapatan. Jadi secara keseluruhan dapat disimpulkan bahwa adanya peningkatan dana transfer untuk tiap-tiap propinsi di Indonesia membawa dampak yang positif terhadap tingkat kemerataan pendapatan antar propinsi di Indonesia. Sirumapea (2007) dalam penelitiannya tentang Dampak Desentralisasi Terhadap Pertumbuhan Ekonomi Kabupaten/kota se Sumatera Utara periode waktu 2001-2004 dengan hasil bahwa desentralisasi fiskal mempunyai pengaruh positif dan signifikan terhadap 
pertumbuhan ekonomi serta faktor populasi penduduk juga mempunyai mempengaruhi positif dan signifikan terhadap pertumbuhan ekonomi dilihat dari produksi dan konsumsi berdasarkan alat analisis Generalized Least Square (GLS)

\section{Kerangka Konseptual}

Keberhasilan ekonomi suatu negara biasanya diukur dari tingginya angka pertumbuhan ekonomi negara tersebut. Namun demikian, terdapat satu ukuran yang lebih representatif dalam melihat keberhasilan ekonomi suatu negara ini, yaitu dilihat dari segi kesejahteraan masyarakatnya dan hal ini dapat dilihat melalui dimensi pemerataan (equality). Pembangunan yang semata-mata mengejar pertumbuhan diyakini akan menghasilkan berbagai kesenjangan dalam kesejahteraan golongan masyarakat (antara golongan kaya dan golongan miskin) maupun dalam bentuk kesenjangan antar daerah atau ketimpangan wilayah. Maka dapat dipahami jika masalah ketimpangan atau kesenjangan antar daerah selalu menjadi salah satu isu utama dalam pembangunan daerah di Indonesia. Seperti yang terdapat dalam Todaro (2006:28), menyebutkan bahwa pembangunan merupakan suatu kenyataan fisik sekaligus tekad suatu masyarakat untuk berupaya sekeras mungkin melalui serangkaian kombinasi proses sosial, ekonomi dan institusional demi mencapai kehidupan yang serba lebih baik.

Ketimpangan yang terjadi antar daerah, baik daerah miskin maupun daerah kaya juga disebabkan karena adanya perbedaan dari faktor pendidikan, jumlah maupun kualitas penduduknya, SDA, letak geografisnya, kesehatan, dan lain-lain. Hal tersebut yang bisa menyebabkan pertumbuhan pendapatan di suatu daerah ada yang tinggi dan ada yang rendah dan juga yang menyebabkan munculnya ketimpangan wilayah.

Faktor lain yang berpengaruh adalah Pengeluaran pemerintah yang mempunyai hubungan negatif dengan ketimpangan wilayah, semakin besar komposisi pengeluaran pemerintah dalam bidang pembangunan akan mengurangi ketimpangan wilayah serta desentralisasi fiskal berepengaruh signifikan terhadap semakin meningkatnya ketimpangan wilayah akibat alokasi Dana Alokasi Umum yang lebih besar kepada wilayah yang juga memiliki sumber daya yang kaya, sehingga akan menimbulkan kesenjangan antar wilayah yang semakin melebar. Rahmat (2013), menyebutkan bahwa Sulawesi Selatan lebih banyak bergantung pada sektor pertanian yaitu sekitar 33,54\%. Selain itu perekonomian Sulawesi Selatan memiliki perkembangan PDRB yang pesat sekitar 7,28 persen per tahun. Namun tejadi ketimpangan yang cukup tinggi. Dari hasil analisis terhadap faktor-faktor yang mempengaruhi ketimpangan di Provinsi Sulawesi Selatan, bahwa desentralisasi fiskal tidak signifikan terhadap ketimpangan wilayah. Tingkat pendidikan SMA tidak signifikan dan berpengaruh negatif sebelum adanya desentralisasi fiskal, sedangkan setelah adanya desentralisasi fiskal berpengaruh positif terhadap ketimpangan. Dan pertumbuhan ekonomi berpengaruh signifikan positif terhadap ketimpangan di Provinsi Sulawesi Selatan.

\section{Hipotesis}


Berdasarkan tinjauan pustaka dan kerangka pemikiran, maka hipotesis yang diajukan dalam penelitian ini adalah:

1. DAK (Dana Alokasi Khusus) berpengaruh negatif dan signifikan terhadap berkurangnya ketimpangan produk domestik regional bruto antara kabupaten provinsi Sulawesi Selatan periode 2006-2014

2. DAU (Dana Alokasi Umum) berpengaruh negatif dan signifikan terhadap berkurangnya ketimpangan produk domestik regional bruto antara kabupaten provinsi Sulawesi Selatan periode 2006-2014

3. DBH (Dana Bagi Hasil) berpengaruh negatif dan signifikan terhadap berkurangnya ketimpangan produk domestik regional bruto antara kabupaten provinsi Sulawesi Selatan periode 2006-2014

Metode Analisis

Data dianalisis dengan menggunakan metode analisa regresi liner berganda yang merupakan metode kuantitatif deskriptif untuk menganalisa data lebih dari satu variabel penelitian.

\section{Indeks Williamson}

Semakin besar angka indeks Williamson ini maka semakin besar pula tingkat ketimpangan yang terjadi. Indeks ini dapat dihitung dengan rumus

$$
\text { dimana: } \quad C V_{w}=\frac{\sqrt{\sum_{i}\left(Y_{i}-\bar{Y}\right)^{2} \cdot \frac{F_{i}}{n}}}{\bar{Y}}
$$

\begin{tabular}{ll}
\multicolumn{1}{r}{$\mathrm{CVw}$} & $=$ Indeks ketimpangan pendapatan wilayah \\
$\mathrm{Fi}$ & $=$ Jumlah penduduk di kab/kota $\mathrm{i}$ \\
$\mathrm{n}$ & $=$ Jumlah penduduk provinsi \\
$\mathrm{Yi}$ & $=$ Pendapatan perkapita di kab/kota $\mathrm{i}$ \\
\multicolumn{1}{r}{} & $=$ Rata-rata pendapatan perkapita untuk seluruh propinsi
\end{tabular}

\section{Uji Asumsi Klasik}

a) Uji Normalitas bertujuan untuk mengetahui apakah residual yang diteliti berdistribsi normal atau tidak. Nilai residual berdistribsi normal merupakan suatu kurva berbentuk lonceng (bell-shaped curve) yang kedua sisinya melebar sampai tidak terhingga. Distribusi data tidak normal, karena terdapat nilai ekstem dalam data yang diambil. (Suliyanto, 2005: 78)

b) Uji Multikolinieritas, diperlukan untuk mengetahui apakah ada tidaknya variabel independen yang memiliki kemiripan dengan variabel independen lain dalam satu model (Nugroho, 2005:58). Selain itu deteksi terhadap multikolinieritas juga bertujuan untuk mengindari bias dalam proses pengambilan keputusan mengenai pengaruh pada uji parsial masingmasing variabel independen terhadap variabel dependen. Deteksi 
multikolinieritas pada suatu model dapat dilihat jika Variance Inflation Factor (VIF) tidak lebih dari 10 dan nilai Tolerance tidak kurang dari 0,1 maka model tersebut dapat dikatakan terbebas dari multikolinieritas. $\mathrm{VIF}=1 /$ Tolerance, jika VIF $=10$ maka Tolerance $=1 / 10=0,1$.

c) Uji Heteroskedastisitas, bertujuan untuk menguji apakah dalam model regresi terjadi pembedaan variance residual suatu proses pengamatan ke periode pengamatan yang lain. Model regresi yang baik adalah model regresi yang memiliki kesamaan variance residual suatu periode pengamatan dengan pengamatan yang lain, atau homokesdastisitas. Cara memprediksi ada tidaknya heteroskedastisitas pada suatu model dapat dilihat dari pola gambar scatter plot model tersebut dan melakukan uji Glesjer (Nugroho, 2005:67)

d) Uji Autokorelasi, dilakukan untuk mengetahui apakah dalam model regresi linear ada korelasi antara kesalahan pengganggu pada periode $\mathrm{t}$ dan dengan kesalahan pengganggu pada periode t-1 (sebelumnya). Jika terjadi korelasi, maka dinamakan ada problem autokorelasi. Autokorelasi muncul karena observasi yang berurutan sepanjang waktu berkaitan satu sama lainnya. Pengujian asumsi ketiga ini, dilakukan dengan menggunakan uji Durbin Watson (Durbin-Watson Test). Yaitu untuk menguji apakah terjadi korelasi serial atau tidak dengan menghitung nilai d statistik. Salah satu pengujian yang digunakan untuk mengetahui adanya autokorelasi adalah dengan memakai uji statistik Durbin Watson (DW test). Jika nilai Durbin Watson berada diantara -2 sampai +2 berarti tidak ada autokorelasi (Nugroho, 2005:68)

\section{Model Pengujian Hipotesis}

a) Koefisien Determinasi $\left(\mathrm{R}^{2}\right)$

Nilai $\mathrm{R}^{2}$ berkisar antara nol dan satu $\left(0<\mathrm{R}^{2}<1\right)$. Nilai $\mathrm{R}^{2}$ yang kecil atau mendekati nol berarti kemampuan variabel independen dalam menjelaskan variasi dependen amat terbatas. Sebaliknya, jika $\mathrm{R}^{2}$ mendekati satu berarti variabel independen memberikan hamper semua informasi yang dibutuhkan untuk memprediksi variasi bariabel dependen (Gujarati, 2003:89)

b). Uji F (Simultan)

Uji $\mathrm{F}$ digunakan untuk menguji apakah secara statistik bahwa koefisien regresi dari variabel independen secara bersama-sama memberikan pengaruh yang bermakna dengan membandingkan nilai probabilitas ( $\mathrm{F}$ statistik) dengan $F$ tabel, dengan ketentuan jika F-statistik>F tabel maka Ho ditolak dan Ha diterima berarti variabel independen berpengaruh signifikan terhadap variabel dependen secara bersama-sama, dengan formulasi hipotesis sebagai berikut: Ho: $\beta_{0}=\beta_{1}=\beta_{2}=0$, variabel independen secara bersama-sama tidak berpengaruh terhadap variabel dependen Ha: $\beta_{0 \neq} \beta_{1 \neq} \beta_{2 \neq} 0$, variabel independen secara bersama-sama berpengaruh terhadap variabel dependen.

c). Uji t (Individu)

Uji t dilakukan untuk mengetahui apakah variabel independen secara individual mempengaruhi variabel dependen. Uji t dilakukan dengan 
membandingkan nilai $\mathrm{t}$ statistik dengan $\mathrm{t}$ tabel. Dalam pengujian ini dilakukan dengan uji 2 sisi dengan tingkat kepercayaan 95\% atau $\alpha=5 \%$ dengan hipotesis Ho: $\beta_{0}=\beta_{1}=\beta_{2}=0$ dan Ha: $\beta 0 \neq \beta_{1} \neq \beta_{2} \neq 0$

Model regresi berganda sebagai berikut:

$\mathrm{Y}_{1}=\mathrm{a}+\mathrm{b}_{1} \mathrm{X}_{1}+\mathrm{b}_{2} \mathrm{X}_{2}+\mathrm{b}_{3} \mathrm{X}_{3}+\mathrm{e}$

dimana:

$\mathrm{Y}_{1} \quad=$ Ketimpangan PDRB

$\mathrm{a} \quad=$ Konstanta

$\mathrm{X}_{1} \quad=$ Dana Alokasi Khusus (DAK)

$\mathrm{X}_{2} \quad=$ Dana Alokasi Umum (DAU)

$\mathrm{X}_{3} \quad=$ Dana Bagi Hasil $(\mathrm{DBH})$

$\mathrm{e} \quad=$ Error term

$\mathrm{b}_{1} \quad=$ koefisien regresi, slope yang berhubungan dengan $\mathrm{X}_{1}$

$\mathrm{b}_{2} \quad=$ koefisien regresi, slope yang berhubungan dengan $\mathrm{X}_{2}$

$\mathrm{b}_{3} \quad=$ koefisien regresi, slope yang berhubungan dengan $\mathrm{X}_{3}$

Definisi Operasional

Untuk menyamakan persepsi tentang variabel-variabel yang digunakan dan menghindari terjadinya perbedaan penafsiran, maka penulis memberikan batasanbatasan definisi operasional sebagai berikut:

1. Ketimpangan produk domestik regional bruto $(\mathrm{Y})$ adalah ketimpangan yang didasarkan pada Indeks Ketimpangan Williamson yang dinyatakan dalam persentase (\%) yang bersumber dari Badan Pusat Statistik Provinsi Sulawesi Selatan.

2. Dana Alokasi Khusus ( DAK) (X1) adalah dana perimbangan dan bersumber dari pendapatan APBN yang dialokasikan kepada daerah tertentu dengan tujuan untuk membantu mendanai kegiatan khusus yang merupakan urusan daerah dan sesuai dengan prioritas nasional.

3. Dana Alokasi Umum (DAU) (X2) adalah dana yang bersumber dari pendapatan APBN yang dialokasikan dengan tujuan pemerataan kemampuan keuangan antar daerah untuk mendanai kebutuhan daerah dalam rangka pelaksanaan desentralisasi pada periode $t$ dalam Rupiah (Rp) yang bersumber dari Dirjen Perimbangan Keuangan Kementerian Keuangan RI.

4. Dana bagi hasil (DBH) (X3) adalah dana yang bersumber dari pendapatan APBN, yang dialokasikan kepada daerah berdasarkan angka persentase tertentu untuk mendanai kebutuhan daerah dalam rangka pelaksanaan desentralisasi pada periode $\mathrm{t}$ dalam Rupiah ( $\mathrm{Rp}$ ) yang bersumber dari Dirjen Perimbangan Keuangan Kementerian Keuangan RI.

Pengukuran Variabel

Untuk mengukur variabel-variabel yang sudah di identifikasi, digunakan instrument dan alat ukur sebagai berikut:

Tabel 2

Operasional Variabel

\begin{tabular}{l|l} 
Karasteristik Daerah & Nama Variabel
\end{tabular}

\begin{tabular}{l|l} 
Indikator & Jenis \\
\hline
\end{tabular}




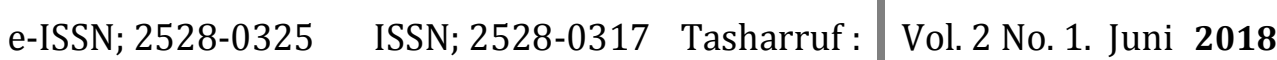
Journal Economic and Business Of Islam

\begin{tabular}{|l|l|l|l|}
\hline & & \multicolumn{1}{|c|}{ Variabel } \\
\hline Ketimpangan Daerah & $\begin{array}{l}\text { Indeks Ketimpangan } \\
\text { PDRB (Y) }\end{array}$ & $\begin{array}{l}\text { Data BPS } \\
\text { Sul-sel }\end{array}$ & Dependen \\
\hline Potensi Daerah & $\begin{array}{l}\text { Dana Alokasi Umum } \\
\text { (DAU) }\end{array}$ & $\begin{array}{l}\text { Data BPS } \\
\text { Sul-sel }\end{array}$ & Independen \\
\cline { 2 - 4 } & $\begin{array}{l}\text { Dana Alokasi Khusus } \\
\text { (DAK) }\end{array}$ & $\begin{array}{l}\text { Data BPS } \\
\text { Sul-sel }\end{array}$ & Independen \\
\cline { 2 - 4 } & $\begin{array}{l}\text { Dana Bagi Hasil } \\
(\text { DBH })\end{array}$ & $\begin{array}{l}\text { Data BPS } \\
\text { Sul-sel }\end{array}$ & Independen \\
& & & \\
\hline
\end{tabular}

Deskripsi Hasil Penelitian

Gambaran Umum dan Keadaan Geografis

Provinsi Sulawesi Selatan yang beribukota di Makassar terletak antara 0o12' - 8o Lintang Selatan dan 116o48' - 122o36' Bujur Timur, yang berbatasan dengan Provinsi Sulawesi Barat di sebelah Utara dan Teluk Bone serta Provinsi Sulawesi Tenggara di sebelah Timur. Batas sebelah Barat dan Timur masing-masing adalah Selat Makassar dan Laut Flores. Jumlah sungai yang mengaliri wilayah Sulawesi Selatan tercatat sekitar 67 aliran sungai, dengan jumlah aliran terbesar di Kabupaten Luwu, yakni 25 aliran sungai. Sungai terpanjang tercatat ada satu sungai yakni Sungai Saddang yang mengalir meliputi Kabupaten Tator, Enrekang dan, Pinrang. Panjang sungai tersebut masing masing $150 \mathrm{~km}$.

Provinsi Sulawesi Selatan terdapat empat danau yakni Danau Tempe dan Sidenreng yang berada di Kabupaten Wajo, serta danau Matana dan Towuti yang berlokasi di Kabupaten Luwu Timur. Adapun jumlah gunung tercatat sebanyak 7 gunung, dengan gunung tertinggi adalah Gunung Rantemario dengan ketinggian $3.470 \mathrm{~m}$ diatas permukaan air laut. Gunung ini berdiri tegak di perbatasan Kabupaten Enrekang dan Luwu. Luas wilayah Provinsi Sulawesi Selatan tercatat 46.083,94 km persegi yang meliputi 21 Kabupaten dan 3 Kota. Kabupaten Luwu Utara kabupaten terluas dengan luas $7.365,51 \mathrm{~km}$ persegi atau luas kabupaten tersebut merupakan 15,98 persen dari seluruh wilayah Sulawesi Selatan. Berikut dapat kita lihat pada tabel 4 tentang jumlah Desa, Kelurahan dan Kecamatan di Kabubaten dan Kota dan table 5 Jumlah luas wilayah menurut Kabupaten dan Kota Provinsi Sulawesi.

Tabel 4

Jumlah Desa, Kelurahan dan Kecamatan di Kabubaten dan Kota Provinsi Sulawesi Selatan Tahun 2014

\begin{tabular}{|c|c|c|c|c|c|}
\hline \multirow{2}{*}{ No. } & \multirow{2}{*}{ Nama Kabupaten } & \multirow{2}{*}{ Kecamatan } & \multicolumn{3}{|c|}{ Klasifikasi Desa/Kelurahan } \\
\hline & & & Kelurahan & Desa & Jumlah \\
\hline (1) & (2) & (3) & (4) & (5) & (6) \\
\hline 1 & Kepulauan Selayar & 11 & 81 & 7 & 88 \\
\hline 2 & Bulukumba & 10 & 109 & 27 & 146 \\
\hline 3 & Bantaeng & 8 & 46 & 21 & 67 \\
\hline 4 & Jeneponto & 11 & 82 & 31 & 113 \\
\hline
\end{tabular}




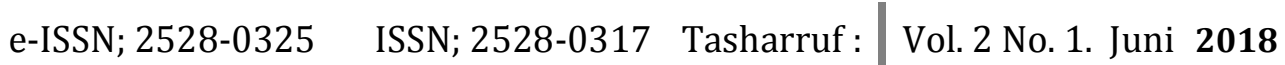
Journal Economic and Business Of Islam

\begin{tabular}{|l|l|c|c|c|c|}
\hline 5 & Takalar & 9 & 76 & 24 & 100 \\
\hline 6 & Gowa & 18 & 122 & 45 & 167 \\
\hline 7 & Sinjai & 9 & 67 & 13 & 80 \\
\hline 8 & Maros & 14 & 80 & 23 & 103 \\
\hline 9 & Pangkep & 13 & 65 & 38 & 103 \\
\hline 10 & Barru & 7 & 40 & 15 & 55 \\
\hline 11 & Bone & 27 & 328 & 44 & 372 \\
\hline 12 & Soppeng & 8 & 49 & 21 & 70 \\
\hline 13 & Wajo & 14 & 142 & 48 & 190 \\
\hline 14 & Sidrap & 11 & 68 & 38 & 106 \\
\hline 15 & Pinrang & 12 & 69 & 39 & 108 \\
\hline 16 & Enrekang & 12 & 112 & 17 & 129 \\
\hline 17 & Luwu & 22 & 207 & 20 & 227 \\
\hline 18 & Tana toraja & 19 & 113 & 47 & 160 \\
\hline 19 & Luwu utara & 11 & 166 & 7 & 173 \\
\hline 20 & Luwu Timur & 21 & 107 & 4 & 124 \\
\hline 21 & Toraja Utara & 14 & 0 & 143 & 143 \\
\hline 22 & Makassar & 4 & 0 & 22 & 22 \\
\hline 23 & Pare Pare & 9 & 0 & 48 & 48 \\
\hline 24 & Palopo & 306 & 2.253 & 785 & 3.038 \\
\hline Sulawesi Selatan & & & 3 & 127 \\
\hline
\end{tabular}

Sumber : BPS, Sulawesi Selatan dalam Angka 2015

Tabel 5

\section{Luas Wilayah Menurut Kabupaten dan Kota} Provinsi Sulawesi Selatan Tahun 2014

\begin{tabular}{|c|c|c|c|}
\hline No. & Kabunaten/Kota & I was Area $\left(\mathrm{KM}^{2}\right)$ & \\
\hline (1) & (2) & (3) & \\
\hline 1 & Kepulauan Selayar & $90.350,00$ & \\
\hline 2 & Bulukumba & $1.154,67$ & \\
\hline 3 & Bantaeng & 395,83 & \\
\hline 4 & Jeneponto & 903,35 & \\
\hline 5 & Takalar & 566,51 & \\
\hline 6 & Gowa & $1.883,32$ & \\
\hline 7 & Sinjai & 819,96 & \\
\hline 8 & Maros & $1.619,12$ & \\
\hline 9 & Pangkep & $1.112,29$ & \\
\hline 10 & Barru & $1.174,71$ & \\
\hline 11 & Bone & $4.559,00$ & \\
\hline 12 & Soppeng & $1.359,44$ & \\
\hline 13 & Wajo & $2.506,20$ & \\
\hline 14 & Sidrap & $1.883,25$ & \\
\hline 15 & Pinrang & $1.961,17$ & \\
\hline
\end{tabular}




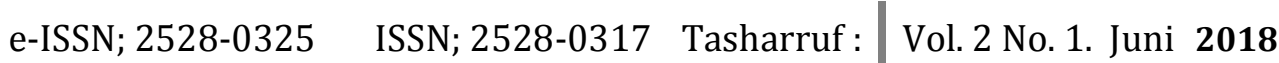
Journal Economic and Business Of Islam

\begin{tabular}{|l|l|c|l|}
\hline 16 & Enrekang & $1.786,01$ & \\
\hline 17 & Luwu & $3.000,25$ & \\
\hline 18 & Tana toraja & $2.054,30$ & \\
\hline 19 & Luwu utara & $7.502,68$ & \\
\hline 20 & Luwu Timur & $6.944,88$ & \\
\hline 21 & Toraja Utara & $1.151,47$ & \\
\hline 22 & Makassar & 175,77 & \\
\hline 23 & Pare Pare & 99,33 & \\
\hline 24 & Palopo & 247,52 & \\
\hline Sulawesi Selatan & $127.708,35$ & \\
\hline
\end{tabular}

Sumber : BPS, Sulawesi Selatan dalam Angka 2015

1. Keadaan Penduduk Provinsi Sulawesi Selatan

Penduduk Sulawesi Selatan Tahun 2014 berjumlah 8.432.163 jiwa yang tersebar di 24 kabupaten/kota, dengan jumlah penduduk ter-besar yakni 1.429.242 mendiami Kota Makassar. Secara keseluruhan, jumlah penduduk yang berjenis kelamin perempuan lebih banyak dari penduduk yang berjenis kelamin laki-laki, Hanya di daerah Kabupaten Enrekang, Tana Toraja, Luwu Utara, Luwu Timur, dan Toraja Utara yang menunjukkan angka penduduk laki-laki di daerah tersebut lebih besar dari jumlah penduduk perempuan.

Berikut dapat kita lihat pada tabel 6, tentang jumlah penduduk dirinci menurut Kabupaten dan Kota Provinsi Sulawesi Selatan:

Tabel 6

Penduduk Menurut Kabupaten dan Kota

Provinsi Sulawesi Selatan Tahun 2014

\begin{tabular}{|l|l|c|c|c|}
\hline \multirow{2}{*}{ No. } & \multicolumn{2}{|c|}{ Kabupaten/Kota } & \multicolumn{3}{c|}{ Penduduk } \\
\cline { 3 - 5 } & \multicolumn{1}{|c}{$(2)$} & Laki-Laki & Perempuan & Jumlah \\
\hline$(1)$ & \multicolumn{1}{|c|}{$(3)$} & $(4)$ & $(5)$ \\
\hline 1 & Kepulauan Selayar & 61.813 & 66.931 & 128.744 \\
\hline 2 & Bulukumba & 192.684 & 215.091 & 407.775 \\
\hline 3 & Bantaeng & 88.012 & 94.271 & 182.283 \\
\hline 4 & Jeneponto & 170.873 & 182.414 & 353.283 \\
\hline 5 & Takalar & 136.350 & 147.412 & 283.762 \\
\hline 6 & Gowa & 114.706 & 360.680 & 709.386 \\
\hline 7 & Sinjai & 164.008 & 122.114 & 236.497 \\
\hline 8 & Maros & 154.608 & 171.588 & 335.596 \\
\hline 9 & Pangkep & 81.105 & 88.6811 & 320.293 \\
\hline 10 & Barru & 352.081 & 386.434 & 738.515 \\
\hline 11 & Bone & 106.206 & 119.503 & 225.709 \\
\hline 12 & Soppeng & 187.215 & 204.765 & 391.980 \\
\hline 13 & Wajo & 139.806 & 146.804 & 286.610 \\
\hline 14 & Sidrap & 176.484 & 187.603 & 364.087 \\
\hline 15 & Pinrang & 99.490 & 98.704 & 198.194 \\
\hline 16 & Enrekang & 170.701 & 176.395 & 347.096 \\
\hline 17 & Luwu & 115.310 & 112.278 & 227.588 \\
\hline 18 & Tana toraja & 150.702 & 149.287 & 299.989 \\
\hline 19 & Luwu utara & & & \\
\hline & & & & \\
\hline
\end{tabular}


e-ISSN; 2528-0325 ISSN; 2528-0317 Tasharruf : $\mid$ Vol. 2 No. 1. Juni 2018 Journal Economic and Business Of Islam

\begin{tabular}{|l|l|c|c|c|}
\hline 20 & Luwu Timur & 138.479 & 130.926 & 269.405 \\
\hline 21 & Toraja Utara & 112.680 & 111.323 & 224.003 \\
\hline 22 & Makassar & 706.814 & 722.428 & 1.429 .242 \\
\hline 23 & Pare Pare & 67.217 & 69.686 & 136.903 \\
\hline 24 & Palopo & 80.410 & 84.493 & 164.903 \\
\hline \multicolumn{2}{|c|}{ Sulawesi Selatan } & 4.116 .737 & 4.315 .426 & 8.432 .163 \\
\hline
\end{tabular}

Sumber : BPS, Sulawesi Selatan dalam Angka 2015

2. Perkembangan Pertumbuhan Ekonomi Provinsi Sulawesi Selatan

Pertumbuhan dan perkembangan PDRB Provinsi Sulawesi Selatan dapat ditinjau dari beberapa indikator makro, yaitu antara lain dari nilai tambah yang dihasilkan struktur perekonomian daerah, laju Produk Domestik Regional Bruto (PDRB) serta PDRB perkapita.

Pertumbuhan ekonomi dapat dilihat dari besarnya nilai Produk Domestik Regional Bruto (PDRB) atas dasar harga konstan yang berhasil diciptakan pada tahun tertentu dibanding dengan nilai tahun sebelumnya. Penggunaan atas dasar harga konstan dimaksudkan untuk menghindari pengaruh perubahan harga, sehingga perubahan yang diukur merupakan pertumbuhan riil ekonomi dan pula merupakan dasar pengukuran atas nilai tambah yang timbul akibat adanya kegiatan ekonomi dalam salah satu daerah. Angka PDRB suatu daerah dapat memperlihatkan kemampuan daerah tersebut dalam mengelolah sumber daya alam yang dimiliki melalui suatu proses produksi. Oleh karena itu besar kecilnya PDRB suatu daerah sangat tergantung pada potensi sumber daya alam dan faktor-faktor yang terdapat di daerah tersebut.

Salah satu cara untuk melihat kemajuan perekonomian suatu daerah adalah dengan mencermati nilai Produk Domestik Regional Bruto (PDRB). PDRB merupakan nilai dari seluruh barang dan jasa yang diproduksi dalam jangka waktu tertentu biasanya dalam waktu satu tahun disuatu wilayah tertentu tanpa membedakan kapemilikan faktor-faktor produksi yang digunakan dalam proses produksi tersebut. Dalam menghitung pendapatan regional hanya dipakai konsep domestik, Berarti seluruh nilai tambah ditimbulkan oleh berbagai sektor atau lapangan usaha yang melakukan kegiatan usahanya di suatu wilayah atau region (provinsi atau kabupaten) dimasukkan tanpa memperhatikan kepemilikan faktorfaktor produksi. Dengan demikian PDRB secara agregatif menunjukkan kemampuan suatu daerah dalam menghasilkan balas jasa atau pendapatan faktorfaktor produksi yang berpartisipasi dalam proses produksi tersebut. Penyajian PDRB selalu dibedakan atas dasar harga konstan dan atas dasar harga berlaku. Adapun definisi PDRB berdasarkan harga konstan adalah nilai barang dan jasa (komoditi) atau pendapatan atau pengeluaran yang dinilai atas dasar harga tetap. PDRB atas dasar harga konstan ini digunakan untuk mengukur pertumbuhan ekonomi karena nilainya tidak dipengaruhi oleh adanya perubahan harga. Sedangkan PDRB atas dasar harga berlaku adalah nilai barang dan jasa (komoditi) atau pendapatan atau pengeluaran yang dinilai sesuai dengan harga yang berlaku pada saat itu atau tahun sekarang, ini digunakan untuk melihat pertumbuhan ekonomi suatu daerah.

Tabel 1

Produk Domestik Regional Bruto Atas Dasar Harga Konstan Provinsi Sulawesi Selatan 
e-ISSN; 2528-0325 ISSN; 2528-0317 Tasharruf : Journal Economic and Business Of Islam

Vol. 2 No. 1. Juni 2018

Tahun 2010-2014

\begin{tabular}{|c|c|c|}
\hline No & Tahun & PDRB (Milyar Rupiah) \\
\hline 1 & 2005 & $36.421,79$ \\
\hline 2 & 2006 & $38.867,68$ \\
\hline 3 & 2007 & $41.332,43$ \\
\hline 4 & 2008 & $44.549,82$ \\
\hline 5 & 2009 & $47.314,20$ \\
\hline 6 & 2010 & $51.199,90$ \\
\hline 7 & 2011 & $55.116,92$ \\
\hline 8 & 2012 & $56.466,90$ \\
\hline 9 & 2013 & $58.123,02$ \\
\hline 10 & 2014 & $59.106,82$ \\
\hline & Total & $488.499,48$ \\
\hline
\end{tabular}

Sumber : BPS Sulawesi selatan, data diolah

Berdasarkan tabel 1 dapat diketahui bahwa jumlah PDRB Provinsi Sulawesi Selatan mengalami peningkatan setiap tahunnya, kenaikan PDRB terbesar terjadi pada tahun 2011, dimana pada tahun 2010 jumalah PDRB Provinsi Sulawesi Selatan sebesar Rp. 51.199,90 Milyar dan 2011 mencapai Rp. 55.116,92 Milyar. Adapun total PDRB dari tahun 2005-2014 Rp. 488.499,48 Milyar. Hal ini menunjukkan bahwa tingkat perkonomian Sulawesi selatan secara keseluruhan mengalami kenaikan.Adapun data pertumbuhan ekonomi provinsi Sulawesi selatan adalah sebagai berikut.

Tabel 2

Pertumbuhan Ekonomi Provinsi Sulawesi Selatan Tahun 2010-2014

\begin{tabular}{|c|c|c|}
\hline No & Tahun & $\begin{array}{c}\text { Pertumbuhan Ekonomi } \\
(\%)\end{array}$ \\
\hline 1 & 2010 & 8,19 \\
\hline 2 & 2011 & 8,13 \\
\hline 3 & 2012 & 8,17 \\
\hline 4 & 2013 & 7,63 \\
\hline 5 & 2014 & 7,57 \\
\hline \multicolumn{2}{|c|}{ Rata-rata } & 7,93 \\
\hline
\end{tabular}

Sumber : BPS Sulawesi selatan, data diolah

Berdasarkan tabel 2 diatas dapat diketahui bahwa pertumbuhan ekonomi provinsi Sulawesi selatan 2010-2014 mengalami fluktuasi. dari tahun 2010-2014 rata-rata pertumbuhan ekonomi Sulawesi selatan 7,93. Hal ini menunjukkan bahwa tingkat pertumbuhan ekonomi Sulawesi selatan secara keseluruhan cenderung positif.

Pertumbuhan perkonomiannya cenderung positif dan kondisi tersebut akan berdampak pada meningkatnya kesejahteraan masyarakat di Sulawesi selatan, Walaupun demikian ketimpangan pembangunan antar daerah masih juga terjadi, 
Disamping ketimpangan pembangunan yang terjadi antar provinsi, ketimpangan pembangunan juga terjadi di kabupaten dan kota di Provinsi Sulawesi selatan. Ketimpangan telah mengakibatkan adanya pembagian wilayah antara Masyarakat Perkotaan, Masyarakat pinggiran serta Masyarakat Pesisir. Timbulnya pembagian wilayah merupakan bentuk kecemburuan masyarakat dari daerah-daerah yang kurang mendapat perhatian dalam pembangunan.

Besarnya PDRB dan pertumbuhan ekonomi menunjukan bahwa perekonomian di Sulawesi selatan tidak mencerminkan kondisi atau corak kehidupan masyarakatnya. Adanya perbedaan potensi dan kondisi geografis sebagai penyebab dalam ketimpangan pembangunan kabupaten dan Kota di Sulawesi selatan, kondisi demografi juga terlihat mengalami ketimpangan. Seperti ketimpangan yang terjadi dalam kualitas tingkat pendidikan masyarakatnya. Rahmat (2013), menyebutkan bahwa Sulawesi Selatan lebih banyak bergantung pada sektor pertanian yaitu sekitar 33,54\%. Selain itu perekonomian Sulawesi Selatan memiliki perkembangan PDRB yang pesat sekitar 7,28 persen per tahun. Namun tejadi ketimpangan yang cukup tinggi.

Kesimpulan

1. Melihat dari masalah yang hendak di selesaikan, tujuan yang hendak dicapai dan hasil pembahasan yang telah dilakukan, maka dari penelitian ini dapat diambil beberapa kesimpulan, yaitu:

2. DAU memiliki hubungan positif dan tidak signifikan terhadap pertumbuhan ekonomi regional tetapi memiliki hubungan negatif dan tidak signifikan terhadap ketimpangan regional. Ini berarti bahwa peningkatan DAU akan mendorong pertumbuhan ekonomi dan menurunkan ketimpangan regional.

3. DBH memiliki hubungan negatif dan tidak signifikan terhadap pertumbuhan ekonomi regional tetapi memiliki hubungan positif dan tidak signifikan terhadap ketimpangan regional. Hasil ini member makna bahwa peningkatan $\mathrm{DBH}$ tidak mampu mendorong pertumbuhan ekonomi dan memperbaiki ketimpangan regional.

4. Pertumbuhan ekonomi regional memiliki hubungan negatif dan tidak signifikan terhadap ketimpangan regional. Artinya, peningkatan pertumbuhan ekonomi akan menurunkan ketimpangan regional.

Daftar Pustaka

Ali, Mohammad. 2009. Pendidikan untuk Pembangunan Nasional. Jakarta: Gramedia Widiasarana Indonesia

Arsyad, Lincolin. 1999. Pengantar Perencanaan Dan Pembangunan Ekonomi Daerah. Yogyakarta: BPFE-Yogyakarta.

Barika. 2012. Analisis Ketimpangan Pembangunan Wilayah Kabupaten/Kota di provinsi Bengkulu Tahun 2005-2009. Jurnal Ekonomi dan perencanaan Pembangunan (JEPP) vol.04 no.03. Universitas Bengkulu.

Badan Pusat Statistik Provinsi Sulawesi Selatan. 2010. Provinsi Sulawesi Selatan dalam Angka 2010. Makassar: Sulawesi Selatan. 


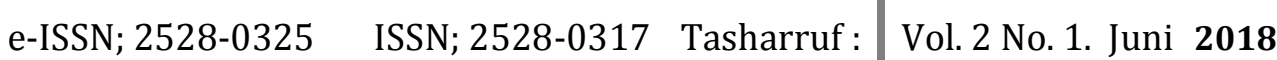
Journal Economic and Business Of Islam

. 2007. Provinsi Sulawesi Selatan

dalam Angka 2011. Makassar: Sulawesi Selatan.

. 2008. Provinsi Sulawesi Selatan

dalam Angka 2011. Makassar: Sulawesi Selatan.

. 2009. Provinsi Sulawesi Selatan

dalam Angka 2011. Makassar: Sulawesi Selatan.

. 2010. Provinsi Sulawesi Selatan

dalam Angka 2011. Makassar: Sulawesi Selatan.

. 2011. Provinsi Sulawesi Selatan

dalam Angka 2011. Makassar: Sulawesi Selatan.

. 2012. Provinsi Sulawesi Selatan

dalam Angka 2011. Makassar: Sulawesi Selatan. 2013. Provinsi Sulawesi Selatan dalam

Angka 2012. Makassar: Sulawesi Selatan.

2014. Provinsi Sulawesi Selatan dalam

Angka 2013. Makassar: Sulawesi Selatan.

2015. Provinsi Sulawesi Selatan dalam

Angka 2014. Makassar: Sulawesi Selatan.

Dumairy. 1996. Perekonomian Indonesia. Jakarta: Penerbit Erlangga.

Darwanto, Herry. Prinsip Dasar Pembangunan Ekonomi Daerah. Diambil dari: http://www.bappenas.go.id/files/5913/5228/1656/heri 2009101510 3733 2313_0.doc, diakses pada 17 September 2014

Dewi, Y. Trias. 2012. "Analisis Ketimpangan Antar Kabupaten/Kota di Provinsi Banten". Tesis. Universitas Indonesia.

Dewangga, L. Putra. 2011 "Analisis Pengaruh Ketimpangan Distribusi Pendapatan Terhadap Jumlah Penduduk Miskin di Provinsi Jawa Tengah Periode 2000-2007”. Skripsi. Universitas Diponegoro.

Harefa, Mandala. Kebijakan Pembangunan dan Kesenjangan Ekonomi antar Wilayah. Diambil dari: http://berkas.dpr.go.id/pengkajian/ files/buku tim/buku-tim-16.pdf,pada tanggal 28 Oktober 2014

Holland, Dawn. et al. 2013. The Relationship Between Graduates and Economic Growth Across Countries. BIS Reseacrh Paper No.110. Diambil

dari:https://www.gov.uk/government/uploads/system/uploads/attac hment data/file/229492/bis-13-858-relationship-betweengraduates-and-economic-growth-across-countries.pdf, diakses pada 25 November 2014.

Jhingan M.L. 2012. Ekonomi Pembangunan dan Perencanaan. Jakarta: PT.Raja Grafindo Persada.

Kuncoro, Mudrajat. 2003. Metode Riset untuk Bisnis dan Ekonomi. Jakarta: Penerbit Erlangga.

2010. Masalah Kebijakan dan Politik Ekonomika Pembangunan. Jakarta: Penerbit Erlangga.

Mopangga, Herwin. 2011. Ketimpangan Pembangunan dan Pertumbuhan Ekonomi di Provinsi Gorontalo. Jurnal Trikonomika 40(1), 40-51.

Program Pascasarjana Universita Muslim Indonesia.2014. Pedoman Penulisan Tesis dan Disertasi.UMI Makassar. 
Rahmat. 2013. Dimensi Strategis Manajemen Pembangunan. Yogyakarta: Graha Ilmu.

Rahmat, Basuki. 2013. Analisis Ketimpangan Wilayah di Provinsi Sulawesi Selatan Sebelum dan Setelah Desentralisasi Fiskal 1990-2011. Skripsi. Universitas Hasanudin Makassar.

Sukirno, Sadono. 2009. Mikro Ekonomi: Teori Pengantar. Jakarta: Raja Grafindo Persada.

Sjafrizal. 2008. Ekonomi Regional Teori dan Aplikasi. Padang: Baduose Media. 2012. Ekonomi Perkotaan. Jakarta: Rajawali Pres . 2014. Perencanaan Pembangunan Daerah dalam Era Otonomi. Jakarta: Rajawali Pres

Subandi. 2011. Ekonomi Pembangunan. Bandung: Alfabeta.

Suparmoko. 2002. Ekonomi Publik: Untuk Keuangan dan Pembangunan Daerah Edisi 1.Yogyakarta: Penerbit Andi.

Tarigan, Robinson. 2005. Ekonomi Regional Teori dan Aplikasi Edisi Revisi. Jakarta: PT Bumi Aksara.

Tambunan, Tulus. 2015. Perekonomian Indonesia Era Orde Lama Hingga Jokowi. Bogor: Ghalia Indonesia

Todaro, Michael P. dan Stephen C. Smith. 2006. Pembangunan Ekonomi. Edisi kesembilan Jilid 1. Devri Barnadi,dkk (Ed). Jakarta: Penerbit Erlangga.

Zakaria, Junaiddin. 2015. Ekonomi Perencanaan dan Pembangunan. Makassar: PT Umitoha Ukhuwah Grafik. 